\title{
Genital Cosmetic Surgery Beyond the Vulvar Anatomy and Function
}

(1) Illker SELÇUK, ${ }^{\text {a }}$

(D) Sibel ORCAN ${ }^{b}$

aDepartment of Gynecologic Oncology, Health Sciences University,

Zekai Tahir Burak Woman's

Health Education and Research Hospital,

${ }^{\mathrm{b} P r i v a t e}$ Practitioner,

Ankara

Received: 26.09 .2018

Accepted: 28.09 .2018

Available online: 25.10 .2018

Correspondence:

İlker SELÇUK

Health Sciences University,

Zekai Tahir Burak Woman's

Health Education and Research Hospital,

Department of Gynecologic Oncology,

Ankara, TURKEY

ilkerselcukmd@ hotmail.com

Keywords: Genital cosmetic surgery; vulvar; anatomy
In the recent years, there is a tremendous interest in genital cosmetic surgery (GCS) and the number of women seeking for a consultation to have a genital cosmetic surgery increases rapidly. Since the most common genital cosmetic procedure is labiaplasty, last decade in Australia, there has been a threefold increase in labiaplasty admissions at the public health system and the total number of GCS related with labias increased 400\% from 2011 to 2015 in United States. ${ }^{1,2}$

The major issues underlying the desire for a GCS are firstly aesthetic reasons to reconstruct an abnormality resulting from birth defect or accident, secondly psychological reasons to improve self-esteem and dissolve anxiety and thirdly functional reasons to reduce pain or discomfort during intercourse or daily activities. The potential effect of media; advertisements and online contents influence women to have an increased concern about the appearance. Moreover, such commercial pressure arising both from the media or products/vision of health care providers will change the normogram of vulvar appearance towards a narrow limit, a unique model. ${ }^{3,4}$

Actually, the true problem is that many women do not know what is the normal vulvar anatomic appearance and function. There is a wide range of normal vulvar morphology in variable colors, size and shape. Some changes in color and size will be physiological during the transition periods from adolescence, pregnancy or menopause; the range of normal size of labia minora is between $20-80 \mathrm{~mm}$ in length and $5-30 \mathrm{~mm}$ in width during this life periods. ${ }^{5}$ By the way, it is so normal to have an asymmetrical or elongated labia minora. Functionally, it has too many small blood vessels, rich in neural network and provides lubrication during intercourse. However, there is a lack of data to predict who will benefit from a GCS, because if the patients are not selected properly the potential harms of surgery like complications (hematoma, scarring, pain, altered sensation or painful intercourse) will overweigh the expectations. On the other hand, sometimes organic pathologies may manifest with dys- 
pareunia (endometriosis) or problems with the partner may reveal a symptom like this, so far we suggest a gynecological examination and if needed a couple therapy before deciding a surgical management.

\section{Source of Finance}

During this study, no financial or spiritual support was received neither from any pharmaceutical company that has a direct connection with the research subject, nor from a company that provides or produces medical instruments and materials which may negatively affect the evaluation process of this study.

\section{Conflict of Interest}

No conflicts of interest between the authors and / or family members of the scientific and medical committee members or members of the potential conflicts of interest, counseling, expertise, working conditions, share holding and similar situations in any firm.

\section{Authorship Contributions}

Idea/Concept: IIlker Selçuk, Sibel Orçan; Design: İlker Selçuk; Control/Supervision: İlker Selçuk; Data Collection and/or Processing: İlker Selçuk, Sibel Orçan; Analysis and/or Interpretation: IIlker Selçuk, Sibel Orçan; Literature Review: İlker Selçuk, Sibel Orçan; Writing the Article: Illker Selçuk, Sibel Orçan; Critical Review: İlker Selçuk.

\section{REFERENCES}

1. Mowat $\mathrm{H}, \mathrm{McD}$ onald $\mathrm{K}$, Dobson AS, Fisher J, Kirkman M. The contribution of online content to the promotion and normalisation of female genital cosmetic surgery: a systematic review of the literature. BMC Womens Health 2015;15:110.

2. Sorice SC, Li AY, Canales FL, Furnas HJ. Why women request labiaplasty. Plast Reconstr Surg 2017;139(4):856-63.
3. Sharp G, Tiggemann M, Mattiske J. Factors that influence the decision to undergo labiaplasty: media, relationships, and psychological well-being. Aesthet Surg J 2016;36(4): 469-78.

4. Reitsma W, Mourits MJ, Koning M, Pascal A, van der Lei $B$. No (wo)man is an island-the influence of physicians' personal predisposition to labia minora appearance on their clinical decision making: a crosssectional survey. J Sex Med 2011;8(8): 2377-85

5. Kreklau A, Vâz I, Oehme F, Strub F, Brechbühl R, Christmann $C$, et al. Measurements of a 'normal vulva' in women aged 15-84: a cross-sectional prospective single-centre study. BJOG 2018 Jun 25. Doi: 10.1111/1471 0528.1587. [Epub ahead of print]. 